\title{
JUDGE VERDICTS ON SUBSIDIARY FINE PENALTY OF CORRUPTION CRIMES (A Case Study on High Prosecutor General Office of NTT) ${ }^{\Omega}$
}

\author{
${ }^{1}$ Sulistyanta and ${ }^{2}$ Henderina Malo \\ ${ }^{1}$ Faculty of Law, Universitas Nusa Cendana, Indonesia \\ E-mail: soelistyanta@gmail.com \\ ${ }^{2}$ Kejaksaan Tinggi Nusa Tenggara Timur, Indonesia \\ E-mail: inamalo13@gmail.com
}

\begin{abstract}
Additional fine penalty in corruption constitutes specific regulation. This aims to restore the state financial loss and to give deterrent effect. Yet, the judge's verdict raises problems: Why do the judge's verdicts related to subsidiary fine penality by imprisonment penalty tend to vary and inconsistent in length of the imprisonment. The purpose of the study is to identify and analyze the judge's consideration in determining various and inconsistent subsidiary fine penalty by imprisonment. The research applied normative juridical method by relying on primary and secondary legal materials. The results show that: 1) judges do not specifically regulate fine penalty or subsidiary in terms of imprisonment penalty. The large amount of fine penalty does not equal to the relatively short imprisonment which does not result in a deterrent effect. 2) There is no limit to the length of imprisonment for a short sentence. Thus, it is suggested that proportional regulation is required between fine penalty and imprisonment penalty subsidiary for restoring state financial loss.
\end{abstract}

Keywords: fine penalty, imprisonment penalty subsdiary, judge's verdict

\begin{abstract}
Abstrak
Pidana tambahan uang pengganti kerugian dalam tindak pidana korupsi merupakan ketentuan khusus. Jenis pidana ini dimaksudkan untuk mengembalikan uang yang dikorupsi juga memberi efek jera. Putusan hakim justru menimbulkan persoalan. Permasalahkan: Mengapa putusan hakim dalam subsidair pidana uang pengganti berupa pidana penjara cenderung bervariasi dan tidak konsisten dalam lama pidananya. Penelitian ini bertujuan untuk mengetahui dan menganalisis pertimbangan hakim menjatuhkan subsidair pidana uang pengganti berupa pidana penjara yang lamanya bervariasi dan tidak konsisten. Penelitian dilakukan dengan metode normatif yuridis yang mengandalkan bahan hukum primer maupun sekunder. Berdasarkan hasil penelitian disimpulkan: 1) Hakim kurang membahas secara khusus pidana uang pengganti maupun subsidair berupa pidana penjara. Putusan berupa pidana uang pengganti yang besar disubsidairkan pidana penjara pengganti relatif singkat, sehingga tidak menimbulkan efek jera. 2). Belum ada batas lama pidana penjara pengganti menimbulkan putusan yang singkat. Saran, perlu peraturan yang secara proposional membandingkan antara besarnya pengganti kerugian negara dengan subsidair pidana penjara.
\end{abstract}

Kata kunci: uang pengganti, subsidair pidana penjara, putusan hakim

\section{Introduction}

Corruption profoundly rooted in most aspects of life in Indonesia becomes social pathology that threatens the aspects of social, nation and state life. Corruption causes massive state

$\Omega$ Result of independent research in NTT High Prosecutor General office in 2015 (Agreement Letter to the head of Lemlit UNDANA No. 340/UN15.19/TU/2017) financial loss.

According to Indriyanto Seno Adji, corruption is a structural crime which involves system, organization and structure; hence, corruption becomes very strong in the context of political and social behavior. Being part of the 
system, corruption eradication is necessarily done by systemic approach. ${ }^{1}$

The state's authority to impose criminal sanction is delegated to law enforcers who work in a particular system known as criminal justice system. The components of this system include police, attorney, court and correctional institution (includes advocate).

The judicial system (in a broader meaning) is identical with "judicial power system" which is actually "law enforcement system". ${ }^{2}$ The judicial system (in a broader meaning) is identical with "judicial power system" which is actually "law enforcement system". ${ }^{2}$ Therefore, judiciary plays an important role in the implementation of criminal justice system. Judge as sub court system implementers is state judicial official who is given the authority by law to judge (Article 1 Paragraph 8 Law Number 8 Year 1981/Criminal Code Procedure).

According to KUHAP (Criminal Code Procedure), verdict can be free from lawsuit or criminal penalty. Judge in deciding the verdict has the freedom to choose the criminal type (strafsort) and how long it will take (strafmaat). In KUHP (Criminal Code), there are principal criminal and additional criminal. Besides, in criminal law aside from KUHP, there is also special additional criminal such as Article 18 Law Number 31 Year 1999 and Law Number 20 Year 2001 on Changes to Law Number 31 Year 1999 on Corruption Crime Eradication.

The main purpose criminal penalties are such as: first, offender's ownership of material rights and convenience; second, offender's activity Freedom; third, offender's reputation/ social status; fourth, offender's social interaction; and fifth, offender's spiritual and prosperity. ${ }^{3}$ The purpose of additional criminal penalty in Corruption Eradication Law of is to give

Indriyanto Seno Adji, Korupsi, 2006, Kebijakan Aparatur Negara dan Hukum Pidana, Jakarta: CV. Diadit Media, p. 384.

2 Barda Nawawi Arief, 2008, Masalah Penegakan Hukum dan Kebijakan Hukum Pidana dalam Penanggulangan Kejahatan, Jakarta: Kencana Prenada Media Group, p.. 43.

3 Fontain Munzil, Imas Rasidawati Wr, Sukendar, "Kesebandingan Pidana Uang Pengganti dan Pengganti Pidana Uang Pengganti dalam Rangka Melindungi Hak Ekonomi Negara dan Kepastian Hukum", Jurnal Hukum IUS QUIA IUSTUM, Vol 22 Issue 1. January 2015. p. 26. deterrent effect to the criminal and restore the state's financial condition. However, based on Kadek Krisna Sintia Dewi's research, the efforts to implement the additional criminal sanction to return the state's loss is not effective yet. ${ }^{4}$ One of the factors of the corruption case increase is the undemanding jugde verdict. Criminal verdicts neither principal penalty nor additional penalty give deterrent effect to the offenders.

Judge's verdict in Prosecutor's Office of NTT is additional penalty in form of money subtitute for imprisonment as it is regulated in Article 18 paragraph (3) Corruption Eradication Law. It is shorter and more varies even with the significant different amount of the subtitute. ${ }^{5}$ Thus, a research aims to analyze the problem related to time period of criminal penalty as subsidiary of fine penalty in High Prosecutor General office of NTT and it is expected to provide theoretical and practical contribution to law enforcement of corruption. Based on the introduction above, the problem of research is: why does verdict of fine penalty for imprisonment tend to vary and inconsistent with the penalty length.

\section{Research Method}

This research was conducted by juridicalnormative approach. Therefore, it emphasizes on primary or secondary data of legal material. Primary data of legal material in form of judge verdicts were obtained from Disrict Court of Ende, Disrict Court of Kupang, Disrict Court of Waikabubak, and Disrict Court of Rote in NTT particularly related to the imprisonment length for state financial loss in corruption. The technique of data collection of legal material was done by literary review.

Analysis was performed by further juridical-normative approach which compared several judge verdicts dealing with returning state financial loss to imprisonment length. By doing

\footnotetext{
4 Kadek Krisna Sintia Dewi, “Efektifitas Penerapan Ancaman Sanksi Pidana Tambahan Guna Pengembalian Kerugian Negara dalam Tindak Pidana Korupsi (Studi Kasus di Pengadilan Negeri Denpasar)", Jurnal Magister Hukum, Vol.7 Issue 3, 2014, p. 364.

5 Data was obtained from Special Criminal Act Council of NTT in 2013.
} 
so, it can be identified whether the amount of state loss and the imprisonment length is proportional or not.

\section{Discussion}

Judge's verdicts in deciding the length of penalty as subsidiary for fine penalty tend to vary and inconsistent. It can be seen in Table 1 . Based on 5 (five) verdicts above, the judges did not particularly examine substitute fine penalty and its subsidiary. Nonetheless, in Article 25 paragraph (1) Law Number 4 Year 2004 on judicial power emphasizes that all of court decisions must contain reason and decision grounds as well as includes the matter of related regulation or unwritten law source used in judging. It is the judge obligation to give adequate consi- deration in the decision. It aims to prevent any power abuse. Incomplete law consideration decision is the reason to submit appeal which potentially cancel the decision. By providing adequate reasons in a judgment, it will be accountable, logical and objective.

Replacing fine penalty by imprisonment in those decisions shows disparity in terms of the length of imprisonment. The researchers argue that it does not fulfill justice value especially legal justice since that decision did not fully implement corruption law which aims to maximize fine penalty to restore the financial state loss and give detterent effect because the convict prefers being imprisoned to return the corrupted money.

Table 1. Judge's verdict in fine penalty and its subsidiary

\begin{tabular}{|c|c|c|c|}
\hline No. & Court's verdict & Fine penalty & Prison penalty \\
\hline 1. & $\begin{array}{l}\text { Verdict of appeal Number: } 109 \mathrm{~K} / \\
\text { Pid.Sus/ } 2009 \text { on } 26 \text { May } 2011 \\
\text { Initiated with court council of Kupang } \\
\text { district court through verdict No.568/ } \\
\text { PID.B/2009/PN.KPG on } 15 \text { April } 2010 \text {. }\end{array}$ & $\begin{array}{l}\text { Rp.16.054.432.972.- } \\
\text { Rp.16.054.432.972.- }\end{array}$ & $\begin{array}{l}3 \text { (three) years imprison- } \\
\text { ment. } \\
3 \text { (three) months imprison- } \\
\text { ment. }\end{array}$ \\
\hline 2. & $\begin{array}{l}\text { Verdict of appeal Number:571K/Pid. } \\
\text { Sus/2012 on April } 11^{\text {th }} 2012 \text {. } \\
\text { Kupang district court decision No. } \\
01 / \text { Pid.Sus/2011/PN.Kpg on October } 12^{\text {th }} \text {, } \\
2011 . \\
\text { Kupang High court decision No. } 01 / \\
\text { PID.SUS/2011/PTK on December } 21^{\text {th }} \\
2011 \text {. }\end{array}$ & $\begin{array}{l}\text { Rp.1.002.167.500.- } \\
\text { Rp.1.002.167.500.- } \\
\text { Rp.1.002.167.500.- }\end{array}$ & $\begin{array}{l}1 \text { (one) year imprisonment. } \\
1 \text { (one) year imprisonment. } \\
1 \text { (one) year imprisonment. }\end{array}$ \\
\hline 3. & $\begin{array}{l}\text { Verdict of appeal Number: } 2 \text { K/Pid.Sus/ } \\
2012 \text { on April } 11^{\text {th }}, 2012 \text {. } \\
\text { Ende district court decision through deci- } \\
\text { sion Number: } 115 / \text { PID.B/2010/PN.KPG on } \\
\text { November } 4^{\text {th }} 2010 \text {. } \\
\text { Kupang high court decision through de- } \\
\text { cision Number: } 206 / \text { PID/2010/PT.K on } \\
\text { February } 18^{\text {th }}, 2011 \text {. }\end{array}$ & $\begin{array}{l}\text { Rp.2.763.058.855,- } \\
\text { Rp.2.763.058.855,- } \\
\text { Rp.2.763.058.855,- }\end{array}$ & $\begin{array}{l}3 \text { (three) months imprison- } \\
\text { ment. } \\
3 \text { (year) months imprison- } \\
\text { ment. } \\
3 \text { (year) year imprisonment. }\end{array}$ \\
\hline 4. & $\begin{array}{l}\text { Verdict of appeal number: } 1137 \mathrm{~K} / \mathrm{Pid} \text {. } \\
\text { Sus } / 2013 \text { on July } 18^{\text {th }}, 2013 \text {. } \\
\text { Criminal corruption court decision in Ku- } \\
\text { pang district court Number: } 20 / \text { Pid.Sus/ } \\
2012 / \text { PN.KPG on December } 17^{\text {th }}, 2012 \text {. } \\
\text { Kupang High court decision Number: } \\
01 / \text { PID.SUS/2011/PTK on December } 21^{\text {th }} \text {, } \\
2011 \text {. }\end{array}$ & Rp.5.080.000.000,- & 1 (one) year imprisonment. \\
\hline 5. & $\begin{array}{l}\text { Rote Ndao state court decision Number: } \\
11 / \text { Pid. Sus/2011/PN.RND date June } 30^{\text {th }} \text {, } \\
2011 \text {. }\end{array}$ & Rp.1.320.000.000.- & $\begin{array}{l}9 \text { (nine) months imprison- } \\
\text { ment. }\end{array}$ \\
\hline
\end{tabular}

Data Source: High Prosecutor General Office of NTT in 2013. 
Moreover, in judging consideration on verdicts, there is no detailed explanation on fine penalty or the subsidairy in form of imprisonment. In fact, it is clearly seen that the article accused by the prosecutor is in conjuction with Article 18 Law of Corruption Eradication. The element of the article should be explained in the consideration or inserted in juridical analysis as the base of the final judgement. It can be seen that the judge paid lack attention to the additional penalty in form of fine penalty and its subsidairy.

According to Article 197 of Criminal Code Procedure, the judges must consider the followings:

Section (1), Penalty Judgement Letter contains:

a. the head of verdict states "FOR THE SAKE OF JUSTICE BASED ON BELIEF IN ONE AND ONLY GOD";

b. the full name, place and date of birth or age, sex, nationality, address, religion, and occupation of the defendant;

c. indictment, as it is written in the letter of indictment;

d. a briefly-arranged consideration on fact, condition, and the proof from the investigation in the trial which becomes the base penalty determination;

e. penalty charge as written in the letter of charge;

f. the article of law which is the base of penalty or act and the article of law which is the legal base of the verdict with the conditions incriminating or relieving the defendant;

g. the day and date of judge panel conference, except the case is investigated by the single judge

h. the defendant's statement of his/her fault which is fulfilled by the elements of criminal act arrangement with its qualifications and the punishment or act executed.

i. The conditions for whom the case costs will discharge, its amount and the proof conditions;

j. The information that all letters are fake and which part indicating the fake, if there is authentic letter, it is considered as the fake one;

k. The command to arrest, keep arresting, or free the defendant;

l. The day and date of the verdict, the name of the public prosecutor, the name of the judge, and the name of the clerk;

Section (2) the unfulfilment of section (1) letter $a, b, c, d, e, f, h, j, k$, and $l$ of this article causes the verdict null and void.

Section (3) The verdict is held immediately according to the conditions in this law.

Based on the conditions, there is no explicit statement forbidding the judge to impose verdict editorially exceeds what has been regulated in Article 197 Law Number 8 Year 1981. Instead, the article which regulates the trial verdict does not contain the verdict content. Therefore, juridically, the judge is allowed to impose verdict containing detail explanation of the implementation of replacement money payment. Thus, if the arrangement of replacement money payment is related to the conditions of Article 197 section (1) letter $h$, the judge is responsible to impose penalty in details. It also means that there is no prohibition for judge to impose punishment in details. In perspective of moral justice, a verdict has to be based on belief in one and only God (Article 2 section (1) Law Number 48 Year 2009), which means that every verdict from the judge belongs to the judge's responsibility toward God and in line with the conscience. Even, the verdict based on this belief is a symbol of the progresive law implementation. The reconstruction of the judge mindset based on progresive law is aimed as a process of rebuilding the judge's mindset in handling a (corruption) case which is based on the basis, concepts, and principles of progresive law in actualizing legal values of executing a case. ${ }^{6}$ These values are reserved and symbolized in every judge verdict which is: "FOR THE SAKE OF JUSTICE BASED ON BELIEF IN ONE AND ONLY GOD".

Based on research conducted on some judges' verdicts, especially in the decision of subsidairy fine penalty by imprisonment can be

Syamsudin, M, "Rekonstruksi Pola Pikir Hakim Dalam Memutuskan Perkara Korupsi Berbasis Hukum Progresif", Jurnal Hukum, No. Edisi Khusus, Vol 18, October 2011, p. 13. 
concluded that the judge only consider the sense of justice from dependants/culprit's point of view. It is proven by the verdict of substitute fine penalty converted to relatively short imprisonment period considered improportional (considering the state loss). In the province of East Nusa Tenggara, classified as a disadvantaged province with relatively low locally-generated revenue, for instance the amount of state losses exceeds Rp.1.000.000.000. (one billion rupiah), a fantastic amount.

The penalty proportionality is essentially relative since in the Corruption Eradication Law does not set guidance on penalty which causes disparity. On the other hand, bad "intention" of the offender is theoretically based on cost and benefits assumption in which he estimates gain and loss before committing his action. He will not commit corruption crime unless he gets profit. The offender will see aspects of rewards and punishment. ${ }^{7}$ This also makes state loss does not fully recovered since the convict prefers being relatively short imprisoned. This results in incomplete justice fulfillment.

The existence of Article 18 Paragraph 3 Law Number 31 Year 1999 by imposing imprisonment (not confinement) as subsidairy of fine penalty is a breakthrough from corruption lawmakers. Because this is different from criminal subsidairy in the Criminal Code as well as other laws in the form of confinement. These particular characteristics should be taken into account by law enforcement officers; it means that judge should maximize subsidairy, as long as the subsidized criminal does not exceed the maximum threat of the principal penalty. The assumption is that if the high-ranking prison crime is "expected", the defendant will choose to pay fine instead of being put in prison for a long time.

However, based on the results of the research, there are some judges' verdicts that do not include imprisonment as subsidairy for fine penalty. Meanwhile, in the prosecution letter, the Prosecutor has filed a fine penalty and sub-

Sulistyanta, "Kebijakan Sanksi Pidana dalam Tindak Pidana Korupsi (Suatu Analisis Empirik)", Jurnal Ilmu Hukum, Vol. 12 No. 1, March 2004, p. 142. sidairy. The judge's verdict should not be significantly different from the prosecutor charges. This means that judicial freedom is juridically limited by what prosecutors charged in the hearing. According to Bobbi Sandri et al, judge's consideration in imposing corporal punishment in lieu of replacement payments is based: (1) investigation on trial, the one who enjoys the money will be proceed to the criminal act of corruption, then it is given to legal institution, (2) based on the prosecutor's charges, (3) based on the judge's conviction as mentioned in Article 184 KUHAP (Criminal Code Procedure).$^{8}$

The following are several Judgment decisions which do not include the substitution of such crimes: ${ }^{9}$ first, Waikabubak District Court verdict Number: 36/Pid.B/2002/PN.WKB on July $9^{\text {th }}, 2002$ with the substitution of Rp.9,659,902. (Nine million six hundred fifty-nine thousand nine hundred and two rupiah); second, Waikabubak District Court verdict Number: 37/Pid.B/ 2002/PN.WKB on August 1st 2002, with a substitute of Rp.28.765.308. (twenty-eight million seven hundred sixty five thousand three hundred and eight rupiah); third, Waikabubak District Court verdict Number: 68/Pid.B/2005/PN. WKB on August $10^{\text {th }}, 2005$ with a substitute of Rp.23.403.200. (twenty-three million four hundred three thousand two hundred rupiah); fourth, Waikabubak District Court verdict Number: $68 /$ Pid.B/2005/PN.WKB on August $10^{\text {th }}$, 2002 with a substitute of Rp.41,416,800. (fourthy one million four hundred sixteen thousand eight hundred rupiah); fifth, Verdict of the Supreme Court of the Republic of Indonesia Number: 24K/Pid.Sus/2012 on February $21^{\text {th }}$, 2012 with a substitute of Rp.108.821.400. (one hundred eight million eight hundred twenty-one thou-sand four hundred rupiah).

Judge does not impose the imprisonment as subsidiary of fine penalty at all. As the result, prosecutor is difficult to execute the ver-

8 Bobbi Sandri et al, "Tinjauan Yuridis Terhadap Putusan Hakim dalam Menjatuhkan Hukuman Badan sebagai Pengganti dalam Pembayaran Uang Pengganti dalam Perkara Pidana", USU Law Jurnal, Vol. 4 No. 2, March 2016, page. 51.

9 Data Source: Procecutor Office of East Nusa Tenggara in 2013. 
dict. It can be seen in the verdict which only contains the sentence "impose fien penalty for about..." without attaching subsidiary imprisonment as replacement if defendant cannot return the state losses. The verdict in the form of replacement money without criminal subsidiary makes the effort to restore the state financial losses even tougher and it does not give deterrent effect to the criminals. For instance, prosecutor in District prosecutor office Waikabubak (until the research is conducted) is still hard to do the execution toward that fine penalty because on one side, the convict has stated his inability to pay (proved by certificate of inability from the authority/local village government). On the other hand, judge does not impose imprisonment as replacement; therefore, the verdict has no forced power for its implementation.

The debts of fine of corruption act in all prosecutor offices in East Nusa Tenggara Province reached Rp.25.400.010.679.- (twenty five billion four hundred million ten thousand six hundred seventy nine rupiahs). This amount is caused by the execution toward the verdict of fine penalty that cannot be fully paid by corruption convicts.

According to Fence M Wantu, many complaints toward the judge's verdict should be noticed. Judicial product in the form of judge's verdict is often considered controversial; it tends to be rejected by community in general. Judge's verdict in court ideally does not cause new problems in society. ${ }^{10}$

Thus, corruption cases increase without satisfying completion triggers the emergence of progressive legal thoughts. This understanding implies that law is under the spotlight. Besides, the problem of law enforcement cannot only be seen from the perspective of law, but also all existing elements such as morality, behavior, and culture. Therefore, new orientation and perspective in law enforcement are needed. Many unsolved corruption cases become the

10 Fence M Wantu," Mewujudkan Kepastian Hukum, Keadilan dan Kemanfaatan dalam Putusan Hakim di Peradilan Perdata", Jurnal Dinamika Hukum, Vol 12 No. 3, September 2012, p. 481. main trigger of emerging progressive legal thoughts. ${ }^{11}$

\section{Conclusion}

Judge in his or her verdict do not exclusively discusses verdict of either fine penalty or subsidiary of imprisonment. The big amount of fine penalty substituted by relatively-short imprisonment causes the convicts prefer being imprisoned to returning the corrupted money. As a result, deterrent effect is not realized. Moreover, there is no guidance for judge to proportionally consider between imprisonment time as subsidiary of fine penalty and the amount of replacement money.

\section{Suggestion}

Clear regulation on imprisonment time determination that proportionally attaches minimum-maximum limit has not existed yet. Hence, this matter needs to be regulated by renewing the legislation.

\section{References}

Ali, Mahrus. "Sistem Peradilan Pidana Progresif: Alternatif dalam Penegakan Hukum". Jurnal Hukum lus Quia lustum. No. 2 Vol. 14. April 2007. Pp. 210-229. DOI: 10.20885/ iustum.vol14.iss2.art2;

Arief, Barda Nawawi. 2008. Masalah Penegakan Hukum dan Kebijakan Hukum Pidana dalam Penanggulangan Kejahatan. Jakarta: Kencana Prenada Media Group;

Arief, Barda Nawawi. "Perlindungan Korban Kejahatan dalam Proses Peradilan Pidana". Jurnal Masalah-Masalah Hukum. No. 5. 1997;

Christianto, Hwian. "Penafsiran Hukum Progresif dalam Perkara Pidana". Jurnal Mimbar Hukum. Vol. 23 No. 3. October 2011. Pp. 479-500. DOI: 10.22146/jmh.16170;

Krisna Sintia Dewi, Kadek, "Efektifitas Penerapan Ancaman Sanksi Pidana Tambahan

\footnotetext{
Mahrus Ali, "Sistem Peradilan Pidana Progresif: Alternatif Dalam Penegakan Hukum", Jurnal Hukum No. 2 Vol. 14 April 2007, hlm 212. Lihat pula dalam Hwian Christianto, "Penafsiran Hukum Progresif Dalam Perkara Pidana", Jurnal Mimbar Hukum, Vol 23 No. 3 October 2011, p. 481.
} 
Guna Pengembalian Kerugian Negara dalam Tindak Pidana Korupsi (Studi Kasus di Pengadilan Negeri Denpasar)". Jurnal Magister Hukum. Vol.3 No. 3 2014. Pp. 357370. DOI: 10.24843/JMHU.2014.v03.i03. p01;

Munzil, Fontain, Imas Rasidawati Wr, Sukendar. "Kesebandingan Pidana Uang Pengganti dan Pengganti Pidana Uang Pengganti dalam Rangka Melindungi Hak Ekonomi Negara dan Kepastian Hukum". Jurnal Hukum lus Quia lustum. Vol. 22 No. 1. January 2015. Pp. 25-53. DOI: 10.20885/ius tum.vol22.iss1.art2;

Safii, Imron. "Urgensi Pengadilan Tindak Pidana Korupsi dalam Mewujudkan Peradilan yang Bersih dan Berwibawa". Pandecta. Vol. 9 No. 1. January 2014. Pp. 76-91. DOI: 10.15294/pandecta.v9i1.2999;

Sandri, Bobbi dkk. "Tinjauan Yuridis Terhadap Putusan Hakim dalam Menjatuhkan Hukuman Badan sebagai Pengganti dalam Pembayaran Uang Pengganti dalam Perkara Pidana”. USU Law Jurnal. Vol. 4 No. 2. March 2016. Pp. 42-55;

Seno Adji, Indriyanto. 2006. Korupsi, Kebijakan Aparatur Negara dan Hukum Pidana. Jakarta: CV. Diadit Media;

Syamsudin, M. "Rekonstruksi Pola Pikir Hakim dalam Memutuskan Perkara Korupsi Berbasis Hukum Progresif". Jurnal Dinamika Hukum. Vol. 11 No. 1. January 2011. Pp. 11-21. DOI: 10.20884/1.jdh.2011.11.1.11;

Sulistyanta. "Kebijakan Sanksi Pidana dalam Tindak Pidana Korupsi (Suatu Analisis Empirik)". Jurnal Ilmu Hukum. Vol 12. No. 1. March 2004. Pp. 141-158;

Sutyoso, Bambang. "Mencari Format Ideal Keadilan Putusan dalam Peradilan". Jurnal Hukum IUS QUIA ISTUM. Vol. 17 No. 2. April 2010. Pp. 217-232. DOI: 10.20885/ iustum.vol17.iss2.art3;

Wantu, Fence M. "Mewujudkan Kepastian Hukum, Keadilan dan Kemanfaatan dalam Putusan Hakim di Peradilan Perdata". Jurnal Dinamika Hukum. Vol. 12 No. 3. September 2012. Pp. 479-489. DOI: 10.20 884/1.jdh.2012.12.3.121. 